\title{
Bașakșehir Devlet Hastanesi Personelinde HBV, HCV ve HIV Seroprevalansı
}

\author{
Hepatitis B, Hepatitis C and HIV Seroprevalance Among Health Care Workers in Bașakșehir \\ Hospital
}

\author{
Funda KOÇAK1, Ediz KIREMIT2, Gülay AKDAĞ1 \\ 1 Başakşehir Devlet Hastanesi, Enfeksiyon Hastalıkları Kliniği, Istanbul, Türkiye \\ 2 Başakşehir Devlet Hastanesi, Mikrobiyoloji Laboratuvarı, Istanbul, Türkiye
}

\begin{abstract}
Anahtar kelimeler: Hepatit B virüsü, hepatit C virüsü, seroprevalans
\end{abstract}
Key words: Hepatit $B$ virus, hepatit $C$ virus, seroprevalance

\section{Sayın Editör,}

Dünyada her yı 35 milyondan fazla sağlık personeli, kontamine tıbbi aletlerle yaralanmaya maruz kalmaktadır (1). Hepatit B virüsü (HBV), Hepatit $\mathrm{C}$ virüsü $(\mathrm{HCV})$ ve insan immün yetersizlik virüsü (HIV) ile enfekte olgularla gelişen yaralanmalar sağlık personeli için risk oluşturmaktadır. Çalışmamızda hastanemizde çalışan 276 sağlık personelinin HBV, HCV ve HIV serolojisini belirlemeyi, HBV'ye karşı bağışıkığı olmayanları saptayıp aşılamayı amaçladık. 01 Kasım-31 Aralık 2012 tarihleri arasında 64 doktor, 108 ebe/hemşire, 48 tıbbi teknisyen ve 56 temizlik personelinde $\mathrm{HBsAg}$, anti-HBclgG, antiHBs, anti-HIV, anti-HCV testleri mikro-ELISA ile çalışıldı.

Çalışmamızda HBsAg pozitifliği \%1,4 olarak tespit edilirken anti-HIV ve anti-HCV pozitifliği saptanmadı. Meslek gruplarına göre HBV duyarlıı̆ı dağılımı tabloda verilmiştir (Tablo 1). Meslek gruplarının HBV'ye karşı bağışı|klık durumlarını karşılaştırdığımızda ise; en yüksek aşılanma oranının doktor grubunda $(\% 81,2)$ ve en düşük aşılama oranının temizlik personeli grubunda $(\% 48,2)$ olduğu tespit edildi. Toplam $3(\% 1,1)$ personelimizde izole anti-HBc total pozitifliği tespit edildi. Ülkemizde sağlık çalışanları arasında HBsAg

\begin{tabular}{|l|c|c|c|c|}
\hline Tablo 1. Meslek gruplarına göre HDV duyarlıı̆ı dağılımı \\
\hline Meslek & Doğal bağışık & $\begin{array}{c}\text { Aşıılı } \\
\text { bağışık }\end{array}$ & $\begin{array}{c}\text { Bağışık } \\
\text { olmayan }\end{array}$ & $\begin{array}{c}\text { HBsAg } \\
\text { pozitif }\end{array}$ \\
\hline Doktor & 12,5 & 81,2 & 4,6 & 1,5 \\
\hline Ebe/hemşire & 18,5 & 72,2 & 6,4 & 0,9 \\
\hline Tıbbi teknisyen & 11 & 60 & 12,5 & 6,5 \\
\hline Temizlik personeli & 16,1 & 48,2 & 32 & 1,7 \\
\hline Toplam & 14,8 & 61,2 & 11,5 & 1,4 \\
\hline
\end{tabular}

pozitifliği \%1,7-17,1, anti-HBs pozitiflik oranı \%17,9-52,9, AntiHCV pozitifliği \%0-1,2 olarak bildirilmiştir (2).Bizim sonuçlarımız bu oranlarla uyumludur. Așıyla önlenebilir hastalıklarda sağlık çalışanları için yürütülecek immünizasyon programı enfeksiyon riskinin en aza indirilmesini etkin bir şekilde sağlamaktadır.

\section{Kaynaklar}

1. Deisenhammer S, Radon K, Nowak D, Reichert J Needlestick injuries during medical training. J Hosp Infect. 2006; 63:263-7.

2. Mıstık R. Türkiye'de viral hepatit epidemiyolojisi yayınların irdelenmesi. Tabak F, Balık I (eds). Viral Hepatit 2007. 1. Baskı. Istanbul: Viral Hepatitle Savaşım Derneği, 2007: 10-5. 